\title{
Histamine Release from Human Leukocytes: Studies with Deuterium Oxide, Colchicine, and Cytochalasin B
}

\author{
Elizabeth Gillespie and Lawrence M. Lichtenstein \\ From the Division of Clinical Immunology, The Johns Hopkins University \\ School of Medicine at The Good Samaritan Hospital, \\ Baltimore, Maryland 21239
}

\begin{abstract}
A B S T RACT Agents known to interact with either microtubules or microfilaments influenced the antigen-induced release of histamine from the leukocytes of allergic individuals. Deuterium oxide $\left(\mathrm{D}_{2} \mathrm{O}\right)$ which stabilizes microtubules and thereby favors their formation enhanced histamine release markedly. Concentrations as low as $5 \%$ increased antigen-induced release somewhat while concentrations as high as $75 \%$ had no effect on release in the absence of antigen. Enhancement occurred over a wide range of antigen concentrations and was also seen when release was initiated by antibody to IgE or IgG. When the release process was divided into two stages a $\mathrm{D}_{2} \mathrm{O}$ activity could be demonstrated only in the second stage. However, when $\mathrm{D}_{2} \mathrm{O}$ was present in the first stage together with agents which raise cyclic AMP levels and thereby inhibit release it partially reversed this inhibition. Colchicine, demecolcine, and vinblastine, compounds known to disaggregate microtubules, i.e., have an effect opposite to that of $\mathrm{D}_{2} \mathrm{O}$, inhibited the release of histamine and counteracted the effects of $\mathrm{D}_{2} \mathrm{O}$. The inhibitory action of colchicine was greater if cells were treated with colchicine before rather than after activation with antigen. Cytochalasin B, a compound which causes the disappearance of microfilaments, had variable effects on histamine release. The most frequently seen response was slight enhancement. Neither $\mathrm{D}_{2} \mathrm{O}$ nor cytochalasin $\mathrm{B}$ altered cyclic AMP levels in leukocytes. These observations support and strengthen the view that an intact and functioning microtubule system is directly important for the secretion of histamine from leukocytes and suggest that microfilaments might have multiple indirect effects.
\end{abstract}

This work was presented in part at the 56th Annual Meeting of the Federation of American Societies for Experimental Biology and appeared in abstract form in 1972 Fed. Proc. 31: 748 .

Received for publication 2 June 1972 and in revised form 18 July 1972.

\section{INTRODUCTION}

Antigen-mediated release of histamine from the leukocytes of allergic individuals is a good in vitro model for allergic reactions. The extent of release correlates well with clinical symptoms (1) and drugs, e.g., isoproterenol and theophylline, which alleviate the in vivo symptoms also inhibit the in vitro release process (2). At the same time the mechanism by which histamine is released from leukocytes is fundamentally similar to the release process in other tissues, with cell-bound antibody ( $\operatorname{IgE}$ ) acting as a receptor and antigen replacing a hormone or other releasing agent.

Colchicine, a drug known to disrupt microtubules, has been shown to inhibit the release of a variety of compounds (3-6) including histamine from leukocytes (7). This observation has been interpreted in all cases as indicating that microtubules play a role in the release process. Deuterium oxide $\left(\mathrm{D}_{2} \mathrm{O}\right)$ which is known to stabilize microtubules $(8,9)$, i.e., act in a manner opposite to colchicine, has been studied in three release systems. In the rat peritoneal mast cell it potentiates the release of histamine by other releasing agents and also acts as a releasing agent itself (3); in the cat adrenal gland it potentiates the release of catecholamines by acetylcholine (6); and in the thyroid gland it inhibits release (10). Recently cytochalasin B, a drug which causes the disappearance of 40-70 A microfilaments from cells but has no effect on the morphology of microtubules $(11,12)$ has been shown to inhibit the release of thyroid hormone and growth hormone $(13,14)$ and potentiate the release of insulin (15).

The present study was designed to evaluate the role of microtubules and microfilaments in the release of histamine from leukocytes through the use of $\mathrm{D}_{2} \mathrm{O}$, colchicine, and cytochalasin $\mathrm{B}$ individually and in combination. It was found that $\mathrm{D}_{2} \mathrm{O}$ potentiated the release process markedly while colchicine and other microtubule dis- 
rupters inhibited release and counteracted the effect of $\mathrm{D}_{2} \mathrm{O}$. Cytochalasin $\mathrm{B}$ had variable effects depending on the individual cells used and the level of histamine release obtained. In the majority of cases it potentiated release somewhat although inhibition was occasionally observed. These results support the view that microtubules are directly important in the release process and suggest that microfilaments have multiple indirect effects.

\section{METHODS}

Leukocytes from allergic individuals were prepared by dextran sedimentation as previously described (16). They were resuspended at a dilution of approximately $10^{7} \mathrm{cells} / \mathrm{ml}$ and incubated at $37^{\circ} \mathrm{C}$ in a medium consisting of (mM): $\mathrm{NaCl}$, $120 ; \mathrm{KCl}, 5 ; \mathrm{CaCl}_{2}, 0.6 ; \mathrm{MgCl}_{2}, 1$; tris (hydroxymethyl) aminomethane, 25 ; human serum albumin, $0.1 \%$, adjusted to $\mathrm{pH}$ 7.4. $\mathrm{D}_{2} \mathrm{O}$ replaced $\mathrm{H}_{2} \mathrm{O}$ in the medium as required. Experiments involving colchicine were also carried out using a phosphate buffer since tris has been reported to interfere with the action of colchicine (17). Under our conditions the effect of colchicine in the two buffers was the same. In experiments designed to study the two stages of the release process (18) cells were exposed to antigen for $2 \mathrm{~min}$ in medium free of calcium and magnesium, washed twice and resuspended in the absence of antigen in the complete medium described above. Histamine released from the cells into the supernatant fluid was measured by a micromodification of the fluorometric technique of Shore $(19,20)$. All experiments were carried out in duplicate and repeated using the cells of at least two and usually three to five different individuals. The average difference between duplicate measurements using this technique was less than $5 \%$.

Cyclic AMP was measured by the protein-binding method of Brown, Albano, Ekins, and Sgherzi (21). This procedure is based on the competition between cyclic AMP in the sample and added radioactive cyclic AMP for a binding

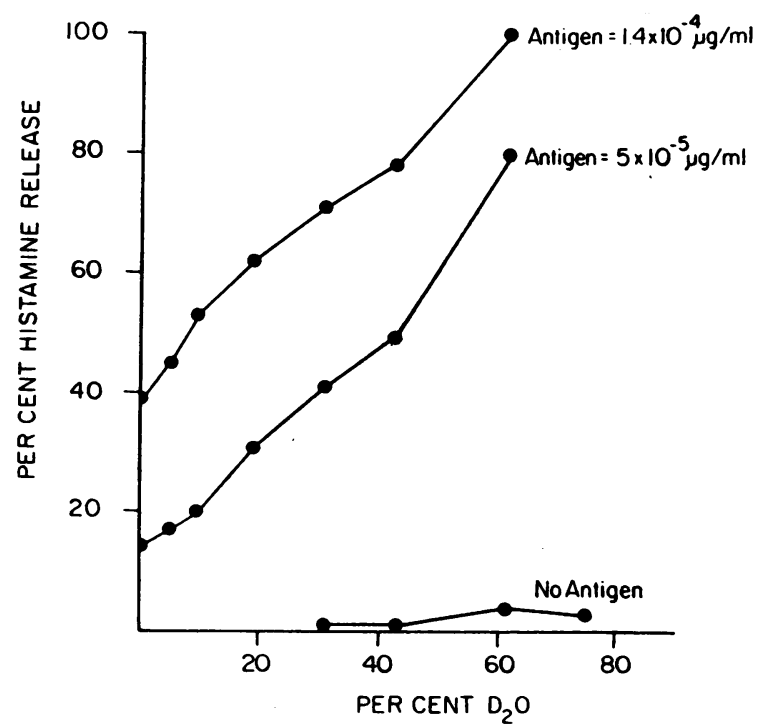

FIGURE 1 The effect of various concentrations of $\mathrm{D}_{2} \mathrm{O}$ on histamine release. Ragweed antigen $\mathrm{E}$ and $\mathrm{D}_{2} \mathrm{O}$ were added at 0 time and the cells incubated for $45 \mathrm{~min}$.

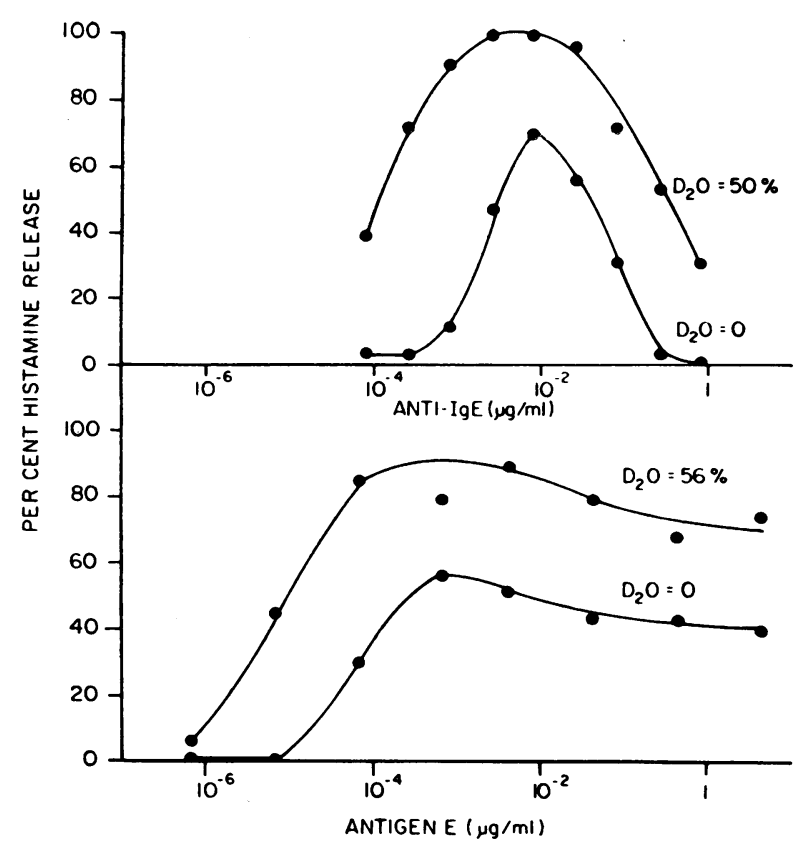

Figure 2 The effect of $\mathrm{D}_{2} \mathrm{O}$ on histamine release induced by either antigen $\mathrm{E}$ or anti-IgE antibody. Releasing agent and $\mathrm{D}_{2} \mathrm{O}$ were added at 0 time and the cells incubated for $45 \mathrm{~min}$.

protein prepared from bovine adrenal cortex. Charcoal is used to separate free and bound nucleotide.

Ragweed antigen $\mathrm{E}$ was provided by Dr. T. P. King (22) and rye grass group I antigen by Dr. D. G. Marsh (23). $\mathrm{D}_{2} \mathrm{O}$ was obtained from BioRad Laboratories (Richmond, Calif.), demecolcine (Colcemid) from Ciba Pharmaceutical Co. (Summit, N. J.), vinblastine sulfate (Velban) from Eli Lilly \& Co. (Indianapolis, Ind.), and cytochalasin B from Imperial Chemical Industries (Alderly Park, England). This last drug was dissolved in dimethylsulfoxide (DMSO) $(10 \mathrm{mg} / \mathrm{ml})$ and diluted as required with incubation medium. DMSO controls were included in all experiments involving cytochalasin B.

\section{RESULTS}

Effects of $D_{2} \mathrm{O}$ on histamine release. $\mathrm{D}_{2} \mathrm{O}$ markedly enhanced the release of histamine from leukocytes under a variety of experimental conditions. $\mathrm{D}_{2} \mathrm{O}$ at levels as low at $5 \%$ significantly increased release due to antigen while concentrations as high as $75 \%$ had no effect in the absence of antigen (Fig. 1). Enhancement occurred over a wide range of antigen concentrations including levels insufficient to cause release alone and levels high enough to inhibit the process (Fig. 2). Enhancement of anti-IgE mediated release (24) was similar in all respects to that noted with antigen (Fig. 2). Potentiation of release by $\mathrm{D}_{2} \mathrm{O}$ was also seen using the cells of individuals who can maximally release only $10-20 \%$ of their total histamine and in situations where the releasing agent usually can induce only a limited response, i.e., 
antibodies to IgG (25) (Fig. 3). When the time course of release was studied, $\mathrm{D}_{2} \mathrm{O}$ increased the rate of release rather than otherwise altering the time course (results not shown). Enhancement of histamine release by $\mathrm{D}_{2} \mathrm{O}$ of the order of magnitude illustrated in Figs. 1-3 was seen in experiments with the cells of all individuals studied (Table I). The per cent enhancement is, of course, related to control release in that if release in the absence of $\mathrm{D}_{2} \mathrm{O}$ is $50 \%$ enhancement cannot exceed $100 \%$ while if control release is $5 \%$ enhancement can be $2000 \%$.

The release of histamine from leukocytes can be operationally divided into two stages, an antigen-dependent, calcium-independent first stage and an antigen-independent, calcium-dependent second stage (18). The effects of $\mathrm{D}_{2} \mathrm{O}$ on the two stages of the release reaction were studied by carrying out either the first or the second incubation in medium containing $\mathrm{D}_{2} \mathrm{O}$. Enhancement occurred only when $\mathrm{D}_{2} \mathrm{O}$ was present during the second stage (Table II).

Interaction between $D_{2} O$ and colchicine, demecolcine, or vinblastine. Since the effects of $\mathrm{D}_{2} \mathrm{O}$ on histamine release are presumably due to its action on microtubules, drugs such as colchicine, demecolcine (Colemid), and vinblastine which disaggregate microtubules should counteract the enhancement of release caused by $\mathrm{D}_{2} \mathrm{O}$. To study this interaction cells were incubated with or without colchicine, demecolcine, or vinblastine for $20 \mathrm{~min}$ at $4^{\circ} \mathrm{C}$., washed and resuspended with antigen in either normal medium or medium in which a portion of the $\mathrm{H}_{2} \mathrm{O}$ was replaced by $\mathrm{D}_{2} \mathrm{O}$. Colchicine, as reported previously (7) inhibited histamine release; inhibition was also observed after treatment of the cells with demecolcine or vinblastine (Fig. 4). In the presence of both $\mathrm{D}_{2} \mathrm{O}$ and

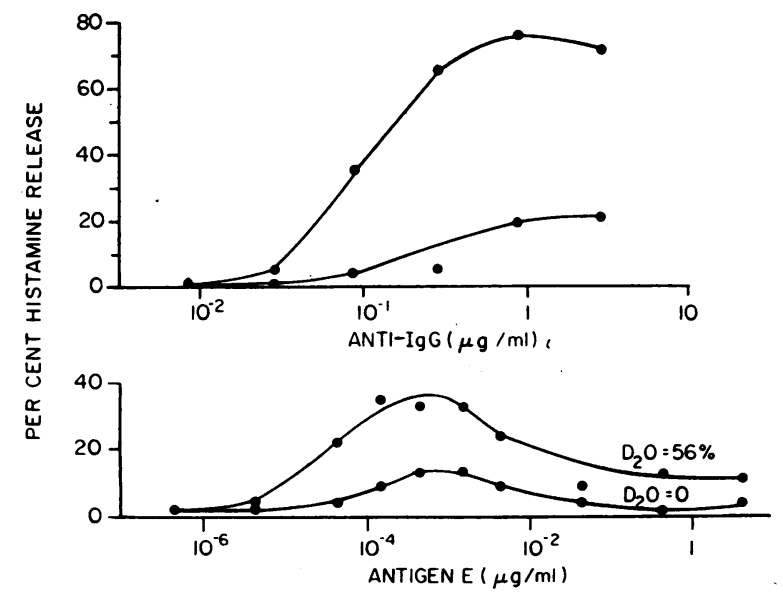

FIgURE 3 The effect of $\mathrm{D}_{2} \mathrm{O}$ on histamine release in situations where maximum release is low. Ragweed antigen $\mathrm{E}$ or anti-IgG and $\mathrm{D}_{2} \mathrm{O}$ were added at 0 time and the cells incubated for $45 \mathrm{~min}$.
TABLE I

Effects of $\mathrm{D}_{2} \mathrm{O}$ on Histamine Release from the Leukocytes of Various Individuals

\begin{tabular}{lcccccr} 
& \multirow{2}{*}{$\begin{array}{c}\text { Control } \\
\text { histamine }\end{array}$} & \multicolumn{5}{c}{ Potentiation by $\mathrm{D}_{2} \mathrm{O}$} \\
\cline { 2 - 6 } Subject & release & $\mathrm{D}_{\mathbf{2}} \mathrm{O}:$ & $7 \%$ & $\mathbf{1 5 \%}$ & $\mathbf{3 1 \%}$ & $\mathbf{6 2 \%}$ \\
\hline & $\%$ & & $\%$ & $\%$ & $\%$ & $\%$ \\
M. C. & $38^{*}$ & & & & 85 & \\
M. C. & 56 & & & & 42 & \\
P. A. & 34 & & 35 & & & 182 \\
B. W. & 14 & & & 100 & 321 & 414 \\
B. W. & 24 & & & 58 & 158 & 316 \\
J. S. & 4 & & & & & 1100 \\
J. S. & 34 & & & & & 162 \\
C. S. & 5 & & & & & 520 \\
M. M. & 13 & & & & & 154 \\
K. B. & 40 & & & & & 85 \\
S. M. & 38 & & & & 68 & 118 \\
D. L. & 50 & & & & 60 & 100 \\
\end{tabular}

* Each number is the average of duplicate measurements in a single experiment. Duplicates did not vary by more than $5 \%$.

either colchicine, demecolcine, or vinblastine, release was always intermediate between that seen in the presence of either alone (Fig. 4). Similar results were obtained in four separate experiments involving $\mathrm{D}_{2} \mathrm{O}$ and colchicine and in two experiments with $\mathrm{D}_{2} \mathrm{O}$ and demecolcine or vinblastine.

Interaction between $\mathrm{D}, \mathrm{O}$ and isoproterenol or prostaglandin Es. Compounds that raise cyclic AMP levels in leukocytes, e.g., isoproterenol and prostaglandins $E_{1}$ and $\mathrm{E}_{2}$, are known to inhibit histamine release through an action confined largely if not completely to the first stage of the process $(26)$. In contrast $\mathrm{D}_{2} \mathrm{O}$ acts only in the second stage (Table II). The interraction between $\mathrm{D}_{2} \mathrm{O}$ and cyclic AMP was studied in two different sets of experiments. In the first set either isoproterenol or prostaglandin $\mathrm{E}_{2}$ was present during the first incubation with

TABLE II

The Effect of $62 \% \mathrm{D}_{2} \mathrm{O}$ on the First and Second Stages of Histamine Release

\begin{tabular}{|c|c|c|c|}
\hline \multirow[b]{2}{*}{ Exp. } & \multicolumn{3}{|c|}{ Histamine release } \\
\hline & $\begin{array}{c}\text { Control } \\
\text { (no } \mathrm{D}_{2} \mathrm{O} \text { ) }\end{array}$ & $\begin{array}{c}\mathrm{D}_{2} \mathrm{O} \\
\text { present, } \\
\text { 1st stage }\end{array}$ & $\begin{array}{c}\mathrm{D}_{2} \mathrm{O} \\
\text { present, } \\
\text { 2nd stage }\end{array}$ \\
\hline & $\%$ & $\%$ & $\%$ \\
\hline 1 & $32 *$ & 32 & 79 \\
\hline 2 & 11 & 13 & 68 \\
\hline 3 & 23 & 25 & 65 \\
\hline
\end{tabular}

* Each number is the average of duplicate measurements in the same experiment. Duplicates did not vary by more than $5 \%$. 


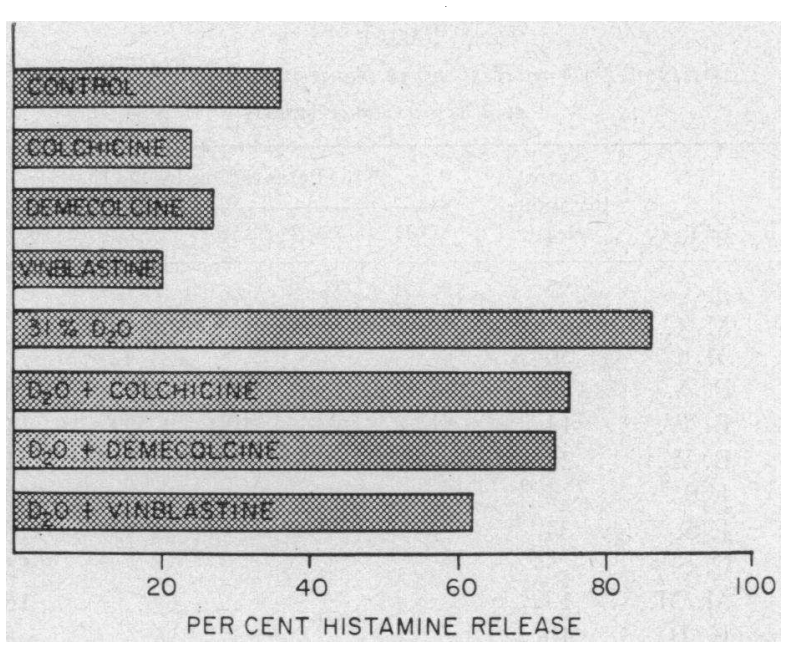

FIGURE 4 Interaction between $\mathrm{D}_{2} \mathrm{O}$ and agents which disaggregate microtubules. Cells were preincubated at $4^{\circ} \mathrm{C}$ with colchicine, demecolcine, or vinblastine $\left(3 \times 10^{-4} \mathrm{M}\right)$ for $20 \mathrm{~min}$. They were then washed twice and resuspended with antigen in $\mathrm{H}_{2} \mathrm{O}$ or $\mathrm{D}_{2} \mathrm{O}$ medium for $45 \mathrm{~min}$ at $37^{\circ} \mathrm{C}$.

antigen and $\mathrm{D}_{2} \mathrm{O}$ was present during the second incubation. Under these conditions isoproterenol and $\mathrm{PGE}_{2}$ inhibited release, $\mathrm{D}_{2} \mathrm{O}$ enhanced it, and the combination of compounds led to intermediate levels of release. Fig. 5 illustrates results obatined using $\mathrm{PGE}_{2}$ to raise cyclic AMP levels.

In the second experimental approach the interaction between $\mathrm{D}_{2} \mathrm{O}$ and either isoproterenol or $\mathrm{PGE}_{2}$ when both were present in the first stage of the release reaction was examined. Cells were first incubated in the

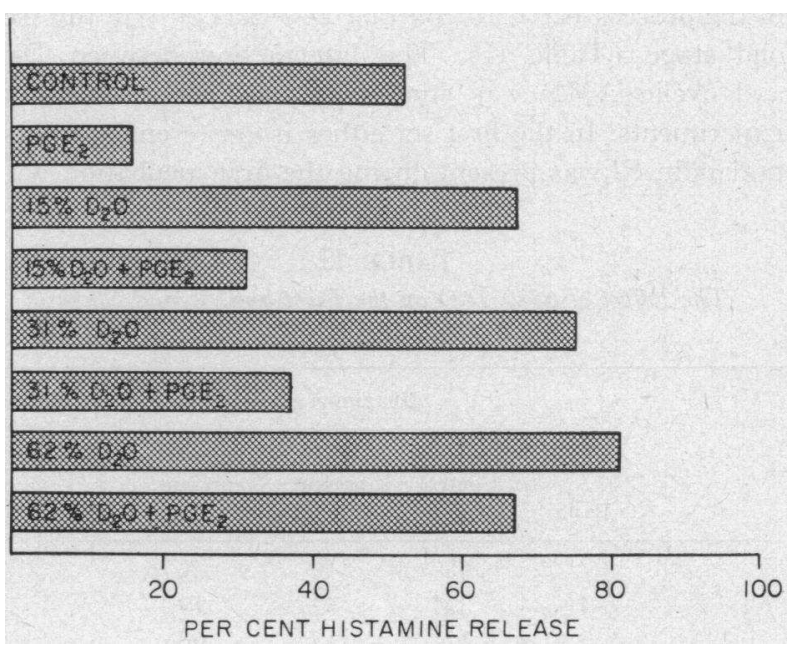

Figure 5 Interaction between $\mathrm{D}_{2} \mathrm{O}$ and prostaglandin $\mathrm{E}_{2}$. Cells were incubated with antigen and $\mathrm{PGE}_{2}\left(1.4 \times 10^{-6} \mathrm{M}\right)$ for $2 \mathrm{~min}$ in the absence of calcium and magnesium, washed twice, and resuspended in $\mathrm{H}_{2} \mathrm{O}$ or $\mathrm{D}_{2} \mathrm{O}$ medium containing calcium and magnesium for $45 \mathrm{~min}$.
TABLE III

Interaction in the First Stage of Histamine Release between $\mathrm{D}_{2} \mathrm{O}$ and Agents which Raise Cyclic AMP Levels

\begin{tabular}{|c|c|c|c|c|}
\hline \multirow[b]{2}{*}{ Exp. } & \multirow[b]{2}{*}{ Addition (X) } & \multicolumn{3}{|c|}{$\begin{array}{c}\text { Inhibition of histamine } \\
\text { release* }\end{array}$} \\
\hline & & $\mathrm{X}$ only & $\begin{array}{l}62 \% \\
\mathrm{D}_{2} \mathrm{O}\end{array}$ & $\begin{array}{c}\mathrm{X}+62 \% \\
\mathrm{D}_{2} \mathrm{O}\end{array}$ \\
\hline & & $\%$ & $\%$ & $\%$ \\
\hline 1 & Isoproterenol $5 \times 10^{-6} \mathrm{M}$ & 60 & 10 & 18 \\
\hline 2 & Isoproterenol $7 \times 10^{-8} \mathrm{M}$ & 57 & $\mathbf{0}$ & 26 \\
\hline 3 & Prostaglandin $\mathrm{E}_{2} 2 \times 10^{-6} \mathrm{M}$ & 90 & 5 & 51 \\
\hline 4 & Prostaglandin $\mathrm{E}_{2} 7 \times 10^{-7} \mathrm{M}$ & 61 & 8 & 0 \\
\hline
\end{tabular}

* Release in the absence of added drugs was $50-80 \%$. The values reported are the average of duplicate determinations which did not vary by more than $5 \%$.

presence of $62 \% \mathrm{D}_{2} \mathrm{O}$ for $10 \mathrm{~min}$. Isoproterenol or $\mathrm{PGE}_{2}$ and antigen were then added for 2 min after which the cells were washed free of all added compounds, resuspended in calcium containing medium and incubated for $45 \mathrm{~min}$. Under these conditions $\mathrm{D}_{2} \mathrm{O}$ partially reversed the inhibition caused by either isoproterenol or $\mathrm{PGE}_{2}$ (Table III). Cyclic AMP was measured after the first incubation period in leukocytes incubated in parallel vessels. $\mathrm{D}_{2} \mathrm{O}$ itself had no effect on cyclic AMP levels and also did not alter the response to either isoproterenol or $\mathrm{PGE}_{2}$.

Effects of colchicine on histamine release before and after treatment of the cells with antigen. The possibility that "activation" of the cells by antigen in the first stage of the reaction involves a change in the state of the microtubule system was investigated by determining the inhibitory effects of colchicine before and after treatment of the cells with antigen. Cells were exposed separately to antigen for $2 \mathrm{~min}$ at $37^{\circ}$ and to colchicine $\left(3 \times 10^{-4} \mathrm{M}\right)$ for $15 \mathrm{~min}$ at $0^{\circ}$ in a calcium and magnesium free incubation medium. The order of treatment was either antigen followed by colchicine or the reverse, colchicine followed by antigen. The cells were washed twice after each treatment and finally resuspended in calcium containing medium for $45 \mathrm{~min}$ at $37^{\circ}$. Histamine release from control cells, i.e., those not treated with colchicine, was unaffected by the difference in handling. The inhibitory action of colchicine was considerably less when the cells were treated with antigen before treatment with colchicine (Table IV).

Effects of cytochalasin $B$ on histamine release. The effects of cytochalasin $B$ on histamine release from the cells of several individuals were examined (Table V). The results varied considerably ranging from inhibition in two cases to moderate enhancement of release in others. Cytochalasin B $(5 \mu \mathrm{g} / \mathrm{ml})$ had no effect on release in the absence of antigen. It also had no effect on cyclic AMP levels in leukocytes after incubation for 
TABLE IV

Effect of Colchicine on Histamine Release before and after Activation of Cells with Antigen

\begin{tabular}{cccc}
\hline & & \multicolumn{2}{c}{$\begin{array}{c}\text { Inhibition by } 3 \times 10^{-4} \mathrm{M} \\
\text { colchicine }\end{array}$} \\
\cline { 3 - 4 } Exp. & $\begin{array}{c}\text { Histamine } \\
\text { release }\end{array}$ & $\begin{array}{c}\text { Before } \\
\text { activation }\end{array}$ & $\begin{array}{c}\text { After } \\
\text { activation }\end{array}$ \\
\hline 1 & $\%$ & $\%$ & $\%$ \\
2 & $89^{*}$ & $31 \pm 3 \ddagger$ & $4 \pm 7$ \\
3 & 49 & $64 \pm 4$ & $24 \pm 4$ \\
62 & $54^{+}$ & 28 \\
\hline
\end{tabular}

* Average of duplicate measurements which differed by not more than $5 \%$.

$\ddagger$ Average of quadruplicate measurements \pm SD.

from 2 to 45 min (eight time intervals studied). The effect of cytochalasin B on the time course of histamine release is shown in Fig. 6. The drug appears to decrease the initial time lag seen before release begins and also increase the rate of release slightly. DMSO at a level equal to that in the cytochalasin solution $(0.05 \%)$ had no effect on the release process.

\section{DISCUSSION}

The present study explores the effects of compounds known to interact with microtubules or microfilaments on the antigen-induced release of histamine from human leukocytes. The results obtained considerably strengthen the view of Levy and Carlton (7) that microtubules are involved in this process. These investigators found that colchicine, a drug which acts by binding to the subunits of microtubules and thereby leading to their disaggregation (27-29) inhibited histamine release. This action of colchicine was considerably enhanced by cold which is known to cause the reversible breakdown of microtubules into subunits $(30,31)$. In the present study we have found that two other drugs, demecolcine and vinblastine, which disrupt microtubules $(32,33)$ also inhibit the release of histamine from leukocytes. At the same time $\mathrm{D}_{2} \mathrm{O}$ which is known to favor the formation of microtubules in other cells $(8,9)$ markedly potentiates antigeninduced histamine release. The enhancement of release caused by $\mathrm{D}_{2} \mathrm{O}$ is greater by far than that seen with any other agent reported to date. The effects of $\mathrm{D}_{2} \mathrm{O}$, unlike those of colchicine, were found to be rapid in onset and readily reversed by removing the $\mathrm{D}_{2} \mathrm{O}$. This made it possible to determine at what stage in the release reaction a functioning microtubule system is required. When the release reaction was divided into two stages $\mathrm{D}_{2} \mathrm{O}$ acted only in the second stage of the process suggesting that microtubules are necessary for the actual secretion of histamine rather than for the initial antigen-induced activation of the process. This finding fits well with the
TABLE V

Effect of Cytochalasin B on Histamine Release from the Leukocytes of Various Individuals

\begin{tabular}{lccc} 
& \multicolumn{2}{c}{ Histamine release } & \\
\cline { 2 - 3 } Subject & Control & $\begin{array}{c}\text { Cytochalasin B } \\
(5 \mu \mathrm{g} / \mathrm{ml})\end{array}$ & $\begin{array}{c}\text { Per cent } \\
\text { change }\end{array}$ \\
\hline & $\%$ & $\%$ & \\
M. K. & $18^{*}$ & 12 & -33 \\
E. E. & 19 & 10 & -47 \\
E. E. (2nd exp. $)$ & 12 & 6 & -50 \\
E. E. & 74 & 82 & +11 \\
D. L. & 61 & 68 & +12 \\
K. B. & 60 & 74 & +23 \\
M. S. & 15 & 24 & +60 \\
M. S. & 45 & 61 & +36 \\
L. W. & 31 & 51 & +64 \\
M. C. & 25 & 43 & +72 \\
L. M. I. & 31 & 59 & +90 \\
L. M. I. & 76 & 100 & +31 \\
\hline
\end{tabular}

* Each number is the average of duplicate measurements in the same experiment which differed by not more than $5 \%$. Dimethylsulfoxide (DMSO) at a level equal to that in the cytochalasin solution $(0.05 \%)$ had no effect on the release process.

idea of others $(3,6,7)$ that the microtubule system is involved in some way with the movement of granules toward the cell membrane.

The interaction seen between $\mathrm{D}_{2} \mathrm{O}$ and isoproterenol or prostaglandin $\mathrm{E}_{2}$ is of particular interest. These latter two compounds inhibit the release of histamine presumably by raising cyclic AMP levels through an action in the first (activation) stage of the release process (26). $\mathrm{D}_{2} \mathrm{O}$, when also present in the first stage, can partially prevent this inhibition. This result has important implications. First since $\mathrm{D}_{2} \mathrm{O}$ alters an event taking place

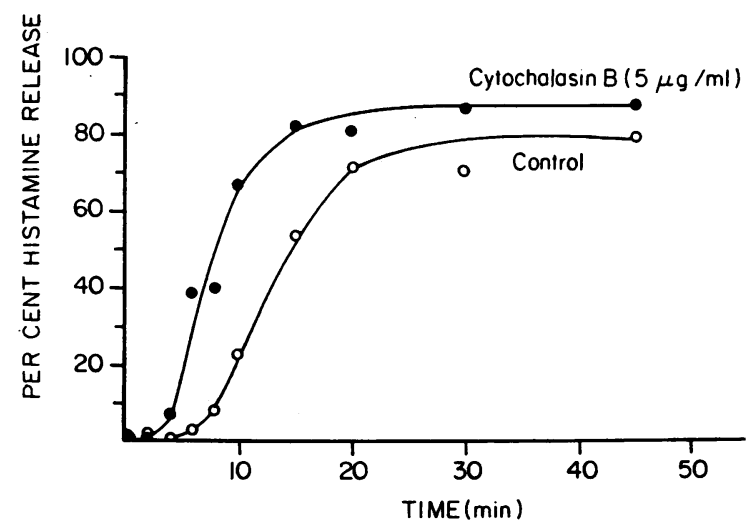

Figure 6 The effect of cytochalasin B on the time course of histamine release. Cytochalasin $B$ and antigen were both added at 0 time. 
in the first stage of the release reaction it suggests that this stage includes a change in the state of the microtubule system. Second it supports the idea that cyclic AMP inhibits release through an action on the microtubule system. Cyclic AMP has been shown to alter the equilibrium between formed microtubules and their subunits in tissue slice preparations (34). In the absence of calcium, the nucleotide promoted the disaggregation of microtubules into subunits, i.e. had an effect opposite to that of $\mathrm{D}_{2} \mathrm{O}$. The present finding that $\mathrm{D}_{2} \mathrm{O}$ partially prevents the inhibition of release by cyclic AMP is consistent with these findings.

The observation that colchicine is a less effective inhibitor of release when the cells are exposed to antigen before rather than after colchicine treatment provides additional strong evidence that the first stage of the release process involves a change in the state of the microtubule system. The change appears to be in the direction of greater microtubule stability since it leads to increased resistance to cold and/or colchicine.

The effects of cytochalasin B on the release of histamine are of interest. This drug, a metabolite of the mold, Helminthosporium dematoideum, has been shown to cause the disappearance of 40-70 A microfilaments but has no apparent effect on microtubules in several cell types $(11,12)$. Its potential effects on metabolism have not been studied in any detail. Cytochalasin B inhibits several processes not known to involve microtubules, e.g. cytokinesis (11), cell motility $(35,36)$, the ingestion step in phagocytosis $(36,37)$, axonal elongation $(38)$, and the dispersal of melanin granules in frog melanocytes $(39,40)$. At the same time it inhibits the release of thyroid hormone (13), growth hormone (14) and histamine from mast cells (41) but potentiates the release of insulin (15). The effects of cytochalasin B on histamine release observed in the present study were variable. The most frequently seen effect was enhancement of release although with the cells of two out of eight individuals significant inhibition of release was observed. These results can best be explained by either assuming that cytochalasin B has two or more independent actions or that its on known action, i.e. disruption of microfilaments can have two or more effects on the release process. The occurrence of microfilaments in basophils does not appear to have been described. In other cell types however microfilaments are frequently found in close association with the cell membrane $(12,42)$. If this is also the case in basophils loss of these microfilaments could well alter the configuration of the membrane which, in turn, could influence both the movement of compounds across the membrane and also the interaction between releasing agents and membrane receptors. The present results with cytochalasin $\mathrm{B}$ are most easily interpreted in this last framework.

\section{ACKNOWLEDGMENTS}

We thank Ms. Jeanne Harrison and Ms. LaVerne Grove for their excellent technical assistance.

This study was supported by Grant AI 07920 from the National Institutes of Health. Dr. Lichtenstein is the recipient of a Research Career Development Award from the National Institute of Allergy and Infectious Diseases.

This is publication No. 42 from the O'Neill Research Laboratories of The Good Samaritan Hospital.

\section{REFERENCES}

1. Lichtenstein, L. M., P. S. Norman, W. L. Winkenwerder, and A. G. Osler. 1966. In vitro studies of human ragweed allergy: changes in cellular and humoral activity associated with specific desensitization. J. Clin. Invest. $45: 1126$.

2. Lichtenstein, L. M., and S. Margolis. 1968. Histamine release in vitro: inhibition by catecholamines and methylxanthines. Science (Wash. D. C.). 161: 902.

3. Gillespie, E., R. J. Levine, and S. E. Malawista. 1968. Histamine release from rat peritoneal mast cells: inhibition by colchicine and potentiation by deuterium oxide. J. Pharmacol. Exp. Ther. 164: 158.

4. Lacy, P. E., S. L. Howell, D. A. Young, and C. J. Fink. 1968. New hypothesis of insulin secretion. Nature (Lond.). 219: 1177.

5. Williams, J. A., and J. Wolff. 1970. Possible role of microtubules in thyroid secretion. Proc. Natl. Acad. Sci.U.S. A. $67: 1901$.

6. Poisner, A. M., and J. Bernstein. 1971. A possible role of microtubules in catecholamine release from the adrenal medulla: effect of colchicine, vinca alkaloids and deuterium oxide. J. Pharmacol. Exp. Ther. 177: 102.

7. Levy, D. A., and J. A. Carlton. 1969. Influence of temperature on the inhibition by colchicine of allergic histamine release. Proc. Soc. Exp. Biol. Med. 130: 1333.

8. Sato, H., S. Inoué, J. Bryan, N. E. Barclay, and C. Platt. 1966. The effect of $\mathrm{D}_{2} \mathrm{O}$ on the mitotic spindle. Biol. Bull. (Woods Hole). 131: 405. (Abstr.)

9. Marsland, D., L. G. Tilney, and M. Hirshfield. 1971. Stabilizing effects of $\mathrm{D}_{2} \mathrm{O}$ on the microtubular components and needle-like form of heliozoan axopods-a pressure-temperature analysis. J. Cellular Physiol. 77: 187.

10. Nève, P., C. Willems, and J. E. Dumont. 1970. Involvement of the microtubule-microfilament system in thyroid secretion. Exp. Cell Res. 63: 457.

11. Schroeder, T. E. 1970. The contractile ring. I. Fine structure of dividing mammalian ( $\mathrm{HeLa}$ ) cells and the effect of cytochalasin B. Z. Zellforsch. Mikrosk. Anat. 109: 431 .

12. Wessels, N. K., B. S. Spooner, J. F. Ash, M. O. Bradley, M. A. Luduena, E. L. Taylor, J. T. Wrenn, and K. M. Yamada. 1971. Microfilaments in cellular and developmental processes. Science (Wash. D. C.). 171: 135.

13. Williams, J. A., and J. Wolff. 1971. Cytochalasin B inhibits thyroid secretion. Biochem. Biophys. Res. Commun. $44: 422$.

14. Schofield, J. G. 1971. Cytochalasin B and release of growth hormone. Nat. New Biol. 234: 215.

15. Orci, L., K. H. Gabbay, and W. J. Malaisse. 1972. Pancreatic beta-cell web: its possible role in insulin secretion. Science (Wash. D. C.). 175: 1128. 
16. Lichtenstein, L. M., and A. G. Osler. 1964. Studies on the mechanisms of hypersensitivity phenomena. IX. Histamine release from human leukocytes by ragweed pollen antigen. J. Exp. Med. 120: 507.

17. Margulis, L., S. Banerjee, and T. White. 1969. Colchicine-inhibited cilia regeneration: explanation for lack of effect in tris buffer medium. Science (Wash. D. C.). $164: 1177$.

18. Lichtenstein, L. M. 1971. The immediate allergic response: in vitro separation of antigen activation, decay and histamine release. J. Immunol. 107: 1122.

19. Shore, P. A., A. Burkhalter, and V. H. Cohen, Jr. 1959. A method for the fluorometric assay of histamine in tissues. J. Pharmacol. Exp. Ther. 127: 182.

20. May, C. D., M. Lyman, R. Alberto, and J. Cheng. 1970. Procedures for immunochemical study of histamine release from leukocytes with small volume of blood. $J$. Allergy. $46: 12$.

21. Brown, B. L., J. D. M. Albano, R. P. Ekins, and A. M. Sgherzi. 1971. A simple and sensitive saturation assay method for the measurement of adenosine $3^{\prime}: 5^{\prime}$-cyclic monophosphate. Biochem. J. 121: 561.

22. King, T. P., and P. S. Norman. 1962. Isolation studies of allergens from ragweed pollen. Biochemistry. 1: 709.

23. Marsh, D. G., F. H. Milner, and P. Johnson. 1966. The allergenic activity and stability of purified allergens from the pollen of common rye grass (Lolium perenne). Int. Arch. Allergy Appl. Immunol. 29: 521.

24. Lichtenstein, L. M., D. A. Levy, and K. Ishizaka. 1970. In vitro reversed anaphylaxis: characteristics of antiIgE mediated histamine release. Immunology. 19: 831.

25. Grant, J. A., and L. M. Lichtenstein. 1972. Reversed in vitro anaphylaxis induced by anti-IgG: specificity of the reaction and comparison with antigen induced histamine release. J. Immunol. 109 : 20.

26. Lichtenstein, L. M., and R. DeBernardo. 1971. The immediate allergic response: in vitro action of cyclic AMP-active and other drugs on the two stages of histamine release. J. Immunol. 107: 1131.

27. Borisy, G. G., and E. W. Taylor. 1967. The mechanism of action of colchicine. Binding of colchicine- ${ }^{8} \mathrm{H}$ to cellular protein. J. Cell. Biol. 34 : 525.

28. Borisy, G. G., and E. W. Taylor. 1967. The mechanism of action of colchicine. Colchicine binding to sea urchin eggs and the mitotic apparatus. J. Cell Biol. 34: 535.
29. Shelanski, M. L., and E. W. Taylor. 1968. Properties of the protein subunit of central-pair and outer-doublet microtubules of sea urchin flagella. J. Cell Biol. 38: 304.

30. Tilney, L. G., and K. R. Porter. 1967. Studies on the microtubules in Heliozoa. II. The effect of low temperature on these structures in the formation and maintenance of the axopodia. J. Cell Biol. 34: 327.

31. Behnke, O., and Forer, A. 1967. Evidence for four classes of microtubules in individual cells. J. Cell Sci. 2: 169.

32. Inoué, S., and H. Sato. 1967. Cell motility by labile association of molecules. The nature of mitotic spindle fibers and their role in chromosome movement. J. Gen. Physiol. 50 (Suppl. 2) : 259.

33. Malawista, S. E., H. Sato, and K. G. Bensch. 1968. Vinblastine and griseofulvin reversibly disrupt the living mitotic spindle. Science (Wash. D. C.). 160: 770.

34. Gillespie, E. 1971. Colchicine binding in tissue slices. Decrease by calcium and biphasic effect of adenosine3',5'-monophosphate. J. Cell Biol. 50: 544.

35. Carter, S. B. 1967. Effects of cytochalasins on mammalian cells. Nature (Lond.). 213: 261.

36. Allison, A. C., P. Davies, and S. de Petris. 1971. Role of contractile microfilaments in macrophage movement and endocytosis. Nat. Nere Biol. 232: 153.

37. Malawista, S. E. 1971. Cytochalasin B reversibly inhibits phagocytosis by human blood leukocytes. Progress in Immunology. B. Amos, editor. Academic Press, Inc., New York. 187.

38. Yamada, K. M., B. S. Spooner, and N. K. Wessells. 1970. Axon growth: roles of microfilaments and microtubules. Proc. Natl. Acad. Sci. U. S. A. 66: 1206.

39. Malawista, S. E. 1971. Cytochalasin B reversibly inhibits melanin granule movement in melanocytes. Nature (Lond.). $234: 354$.

40. McGuire, J., and G. Moellmann. 1972. Cytochalasin B: effects on microfilaments and movement of melanin granules within melanocytes. Science (Wash. D. C.). $175: 642$.

41. Orr, T. S. C., D. E. Hall, and A. C. Allison. 1972. Role of contractile microfilaments in the release of histamine from mast cells. Nature (Lond.). 236: 350 .

42. Schroeder, T. E. 1968. Cytokinesis: filaments in the cleavage furrow. Exp. Cell Res. 53: 272. 